\title{
Organizational Ethics and Employee Level of Productivity in Nigerian Private Universities
}

\author{
Agboola, Gbenga Mayowa \\ Department of Business Management, School of Business, College of Development Studies, Covenant \\ University, Ota, Ogun State, Nigeria. \\ Epetimehin, Oluwagbenga Samuel \\ Department of Business Management, School of Business, College of Development Studies, Covenant \\ University, Ota, Ogun State, Nigeria. \\ Akinyele, Samuel Taiwo \\ Department of Business Management, School of Business, College of Development Studies, Covenant \\ University, Ota, Ogun State, Nigeria. \\ Ashipaoloye, Francis Kayode \\ College of Business and Accountancy \& Program Chair for Graduate School, Lyceum of the Philippines \\ University-Laguna, Philippines.
}

\begin{abstract}
Employee level of productivity is one of the many possible outcomes of ethical issues in an organization. An organization with strong ethical beliefs leads to a greater sense of commitment among its employees. The purpose of this research paper was to establish the relationship between organizational ethics and employee level of productivity in higher education institution (private university) in Nigeria. The researcher utilized both explorative and cross-sectional survey research method to gather the needed information. The participants of the study were faculty of Covenant University from the College of Development Studies (CDS) and College of Science and Technology (CST). The population for this study was 390 academic staff of Covenant University out of which a sample of 198 participants were determined using Yard's formula. The gathered data were analysed with the use of frequency, percentage, standard multiple regression analysis and correlation analysis. The findings of the study revealed that Wasted Time, Leisure, Degree of Gratification, Self-Reliance, Centrality of Work, Hard Work, and Morality are not statistically significant to employee rewards and hours worked. The study recommends that: 1.) Private universities should embark on creating leisure periods for their faculty in order to increase their level of productivity; 2.) Private universities should continue to use reward system and increase promotion as a way of maintaining faculty loyalty.
\end{abstract}

Keywords: Organizational Ethics, Productivity, Employee, Private University, Reward, and Work Hours.

\section{Introduction}

An organization with strong ethical beliefs promotes a stronger commitment within that organization (Valentine and Barnett, 2003). There is no perfect world. However, most organizations perceive ethics and core values as fundamental to the organization's reputation due to its direct influence on the overall success of the company. (Rogers, 1994). Therefore, an organization is obliged to disburse values, standards, and expectations in their code of ethics. Ethics within an organization goes beyond abiding by rules and obeying orders. It also deals with adding meaning, purpose, and a strong sense of community within the organization.

On the other hand, employee level of productivity is one of the many possible outcomes of ethical issues in an organization. Studies and researches undertaken on the measures to increase employee productivity reveal the significant role played by the leadership, culture, and motivational levels of employees within an organization. Increasing attrition rates, grievances among employees, high levels of stress and burnouts, low employee morale, absenteeism and the like are the major indicators and consequences of degrading employee level of productivity (Mheta and Joshi, 2010). These causes are sometimes attributed to the nature of leadership style, motivational tools, organizational culture, and personal factors of employees such as their role conflicts, values, beliefs, feelings, attitudes, perceptions, and goals.

Work (organizational) ethic is a cultural norm that argues in favour of being personally accountable and responsible for the work that one does and is based on a belief that work has intrinsic value (Brauchle and Azam, 2004). The term is applied to characteristics of people, both at work and at play (Brauchle and Azam, 2004). Private universities in Nigeria have peculiar methods of conducting work in order to ensure the accomplishment of goals and objectives in an educational environment.

Like other organizations, private universities in general have their own ethical norms to guide employees in their duties. For example, most private universities in Nigeria have core values that guide the conduct of their 
staff and students. Consequently, employees are rewarded based on how they comply with the set organizational ethics. Some employees often want to get rewarded for carrying out their duties without applying the set organizational ethics such as hard work and punctuality. These employees end up missing their rewards. The effect of rewarding positive work ethics and punishing negative work ethics of peers at work has improved levels of ethical expectancies and ethical decisions (Kurland, 1995). Since rewards may be viewed as moral or material, compliance with moral rules enables employers to judge employees work ethics and as such motivate them through rewards.

Thus, the need to understand the extent of the relationship between organizational ethics and employee level of productivity is inevitable for better performance.

\subsection{Statements of Research Problem}

In the past decade, there has been a great deal of attention placed on the ethical failures of business and industry in Nigeria. Widespread Internet and television coverage has damaged the reputations of many businesses and eroded the trust of stakeholders. Almost every day in business and industry, there is unsettling news about the abuse of power, disregard for human welfare, sexual misconduct, embezzlement, discrimination, etc. There are renewed interest among contemporary researchers on ethical issues and behaviours of corporate leaders and the extent to which these issues and behaviours affect the level of employee productivity.

Ethics is the study of systems, norms, or values that distinguish between good and bad or right and wrong. Its primary focus is on conduct and policies within the context of commercial enterprise (Mote, Jordan, and Hage, 2007). The term work ethics describe an area of applied ethics. It consists of applying moral right and wrong to technologies, transactions, activities, and ventures to commerce or business. Fairness, transparency, and individual ambitions all play major roles in business (organizational) ethics, with profit being the primary goal (Velasquez, 2006).

It has been observed that average workers generally prefer less number of work hours. As a result of this, employees take excessive breaks or sick leaves just to get away from spending long hours working. This is described as having poor work ethics. Similar characteristics are found in Nigerian private universities. It is observed that employees would prefer to spend more hours on leisure activities such as spending time with families and engaging in other social activities other than work. Effective employees on the other hand would rather prefer longer hours of work, in the form of overtime and can be said to have strong work ethics. These employees believe that spending more hours on work would enable them get additional pay for possible leisure activities in the future (Pozen, 2008). Consequently, managing employees' work ethics has become a major problem for private universities.

\subsection{Research Questions}

a. Are the contributions of organizational ethics on employee rewards in Nigerian private universities significant?

b. What are the predictive capabilities of organizational ethics on employee work hours in Nigerian private universities?

\subsection{Research Objectives}

The general objective of this study was to determine the extent of relationships between organizational ethics and employee level of productivity of Nigerian private universities.

In attaining the above, the specific objectives are as follows:

a. To determine the contributions of organizational ethics on employee rewards in Nigerian private university.

b. To determine the contributions of organizational ethics on employee work hours in Nigerian private university.

\subsection{Research Hypotheses}

To address the above objective, the following hypotheses were developed to provide a testable expectation of empirical reality:

$\mathrm{H}_{1(0)}$ : The contributions of organizational ethics on employee rewards in Nigerian private universities are not significant.

$\mathrm{H}_{2(0)}$ : The predictive capabilities of organizational ethics on employee work hours in Nigerian private universities are not significant.

\section{Literature Review}

2.1. Concept of Ethics:

According to Al-Maududi (1967), the following were outlined as work ethics: (1) The need to educate both employee or employer on the obligation to perform their responsibilities decently. ${ }^{(2)}$ It is imperative to categorize between lawful or unlawful professions. ${ }^{(3)}$ That ethics must be universal in nature, so that it could be embraced by any society irrespective of religion, skin colour, race, or ethnic. ${ }^{(4)}$ Since Islam is a religion that stresses upon peace 
and harmony, ethics must be well assimilated by human nature. ${ }^{(5)}$ Ensuring that each job is performed decently. The importance of instilling internal values in individuals with high esteems was stressed by Maskawyh (1961), these values are seen as the major influence in spur-of-the-moment decision-making and it could be categorized into two parts: one that is natural, such as feelings of anger and fear. The second part is trained through traditions, inherited from family socializing processes.

The term ethics was derived from the Greek word "ethos" which refers to values and attitude that indicates one's character or society's stance (Garner, 1984). Furthermore, ethics is defined as a moral philosophy that distinguishes between good and bad that covers traditions and norms accepted by a society (Gwin, 1985).

High moral values can be developed in individuals through positive values, instilled by family and other socialization agents such as school, mosque and others, which would reflect in manner and conduct. By stressing upon positive attributes in work ethics, it is possible to train workers on how to avoid indecent acts when performing their duties. (Al-Ghazali, 1997).

\subsection{Organizational Ethics versus Employee Level of Productivity:}

Many business researches and studies are dedicated to promote the area of productivity of their employees. In order to gain market advantage, organizations are attracting and retaining potential employees who can deliver the desirable performance.

Organizations expect employees to behave in a manner consistent with the organization's vision, mission, goals and objectives. By setting standards for organizational conduct, organizational executives set expected behaviour. An employee showing a positive attitude towards maintaining the set standards of the organization is likely to create an environment conducive for customers, suppliers, partners and stakeholders.

Aside from the commitment of the organization in setting ethical standards, the organization also has the responsibility of keeping their employees' dedication at work. In organizational ethics, part of the responsibilities of the organization and expected employee commitments are enclosed in the core values and principles of the organization. The organizational ethics are also a guideline that the organization and their executives can use to generate sound decisions. This is so because the organizational ethics comprise of the set standards articulated in law and regulations, internal policy, and procedures. Being honest, working with integrity, respect, and fairness are based on the principles, which are expected from employees and customers in terms of product quality, health, safety, and efficiency.

Employers often cite a strong work ethic as the most desired characteristic in a new employee (Denka, 1994; Hill and Petty, 1995; Young, 1986,). Work ethic can be described as a set of characteristics and attitudes in which an individual worker assigns importance and merit to work (Hill, 2005). Those with a strong work ethic place a positive value on doing a good job and describe work as having an intrinsic value of its own (Cherrington, 1980; Yankelovich and Immerwahr, 1984). According to Hill (2005), employers seek employees who are dependable, have good interpersonal skills, and demonstrate initiative. Prior research has associated these characteristics with a high level of work ethic (Hill \& Petty, 1995). Since organizations are able to identify whether an employee carries a strong work ethic, then it is likely that the employee will have a high level of productivity Cherrington, 1980; Yankelovich and Immerwahr, 1984).

Employers value a strong organizational ethic because of the economic benefits it provides to the organization (Ali \& Falcone, 1995). This indicates that an employee who does not have sufficient commitment to work and lacks dependability, interpersonal skills, or imitativeness is capable of putting the organization at risk of low or no productivity.

\subsection{A Traditional African Perspective on Work Ethic:}

Cultural values in Africa traditions reveal that people hold a view of moral truth by which they look for how to structure not just their lives but their comprehension of the universe. A strong belief about common human decency, whether good and bad, correct behaviour and upright behaviour towards other human beings, were acquired from the fore-fathers and passed down to the upcoming youths as part of the common cultural heritage. Selflessness and kindness were exalted. Individuals were obliged by custom as well as conscience to be compassionate, courteous and thoughtful towards others. African workmen drew heavily upon this cultural arsenal in planning, organizing and offering potential solutions for the various the day-to-day concerns and contemporary problems encountered. The fundamental notion embodied in the concept 'Ubuntu' referring to a sense of identity emerging from an individual's place in society, (Higgs, Vakalisa, Mda and Assie-Lumumba, 2000) was in the marrow of a militant, self-conscious working-class ethic. A central motif related to this proposition, and one for which the evidence is extraordinarily conclusive, is alien, though these expressions might have seemed to the colonists, the entire body of African workers adhered firmly to a code of ethical conduct that cannot be dismissed. What is more, they brought sanctions to bear upon anyone who infringed upon the moral norm.

Writers (Khuba, 1985; Atkins, 1993; Mafunisa, 1998; Sitoto, 2002) repeatedly stress the concept of hierarchy, with its differentiation of power and roles, as an abiding feature of African society. Migrant workers 
were familiar with the organized social structure that dictated power and status of individuals. They were accustomed to self-regulation and discipline; moreover, they had recognized rules and approved patterns of behaviour to which they were expected to conform. Individuals who transgressed the work code were sternly chastised by the leadership. Chastisement was accepted as the 'right of the elder' who was also the leader (Russel, 1899). Ideas, values and emotions that formed their cultural matrix, constituted what may be recognized as an African work ethic. Nineteenth century African workmen had effective organizational structures and clear notions of power relationships based on position and status. Adherents of African traditional religions believe that a lack of respect towards one's superiors equates to a lack of respect for the ancestors who are responsible for blessings at work such as promotion and salary increments (Mafunisa, 1998). An African work ethic could therefore be seen as that which emerged from the traditional religious practice, including ancestor veneration, as well as the basic existential conditions in which the people lived, grounded in their consideration for human well-being (Sitoto, 2002).

An African work ethic is a complex phenomenon. It consists of an unquestioning adherence to the predominant group ideology; rewarding expectations stemming from a patriarchal society; the right of young adults to pursue and express their talents within the limitation of organized structure and positional power delineations. The expectation of individual reward equivalent to services rendered which at the same time ensure the well-being of an entire society.

\section{Methodology}

The method adopted in this study was the exploration research method. Another method used was the crosssectional survey research method in order to gather relevant questions from knowledgeable employees' ideas through the use of well-constructed questionnaire which provided participants responses. The information derived through questionnaire formed the basis for the study. In the use of questionnaires, the variables involved in the research were observed at one or more points in time as they were without making any attempt to control or manipulate them. The participants of the study were the academic staff of Covenant University in Ogun State. The reason for the use of Covenant University was because it was the best private university in Nigeria as at the end of 2013 (Ranksng, 2013 and Campus Portal, 2013).

The population of this research study consisted of three hundred and ninety (390) employees, which were made up of the academic staff of Covenant University. The departments considered were selected based on purposive/judgmental basis, which were College of Development Studies (CDS), College of Science and Technology (CST) and Center for Learning Resources (CLR). This was due to time limitation. The sampling frame for this covered only the academic staff of Covenant University. The sample frame was drawn from a list of academic employees provided by University's Staff Records Unit of the Registry Department. The sample size for this study was based on the Yard's formula. A hundred and ninety eight (198) academic staff were arrived at after using stratified sampling technique. The copy of questionnaires that were distributed to the three locations, CDS, CST and CLR, were determined using stratified sampling. Copies of the questionnaire were administered to the academic staff based on their availability. Below is table 1 , showing the sharing ratio for copies of the questionnaire to the three locations in Covenant University.

Table 1: Ratio for Sharing Questionnaires

\begin{tabular}{|l|l|l|l|}
\hline \multicolumn{1}{|c|}{ University } & College/department & Number of population & \multicolumn{1}{c|}{ Stratified sampling } \\
\hline Covenant University & CDS & 156 & 80 \\
\hline & CLR & 18 & 8 \\
\hline & CST & 216 & 110 \\
\hline Total & & $\mathbf{3 9 0}$ & $\mathbf{1 9 8}$ \\
\hline
\end{tabular}

Source: Researcher's Field Survey (2014)

A structured questionnaire was used to obtain data needed for the research. The questionnaire contained pertinent questions to the study which was distributed to participants of the research based on a 5-Point Likert Scale with the following verbal interpretation: Strongly Agree (SA), Agree (A), Undecided (U), Disagree (D) and Strongly Disagree (SD). The questionnaire was divided into three sections, sections A, B and C. Section A contained information on the demographic characteristics of respondents; their gender, age, marital status, educational background, position occupied in the organization etc. Section B and section C were the main thrust of the questionnaire and were focused on the variables identified for the study that is the organizational ethics and employee level of productivity. 
Table 2: Rate of Response

\begin{tabular}{|l|c|c|}
\hline \multicolumn{1}{|c|}{ Questionnaire } & Respondents & Percentage \\
\hline Returned & 150 & $75 \%$ \\
\hline Not Returned & 50 & $25 \%$ \\
\hline Total Distributed & $\mathbf{2 0 0}$ & $\mathbf{1 0 0 \%}$ \\
\hline
\end{tabular}

Source: Researcher's Field Survey (2014)

Two hundred (200) copies of the questionnaire were administered in order to increase response rate. In the table below, $150(75 \%)$ copies of the questionnaire were filled and returned and $50(25 \%)$ copies of the questionnaires were not returned.

The Cronbach's Alpha was used to determine the reliability of the research instrument. The reliability statistic showed a coefficient of .811, indicating high reliability from the views of (Nunnally, 1978) and (George and Mallery, 2003). The procedures for processing the data was done through the use of analytical software called the Statistical Package for Social Sciences (SPSS) version 21. All the items in the questionnaire were analysed.

\section{Result}

The frequency distribution of the respondents' bio-data is presented in table 3 below. It shows the frequency, percent and cumulative percent of each item of the respondents' bio-data. 
Table 3: Frequency Distribution of Respondents' Bio-Data (Section A)

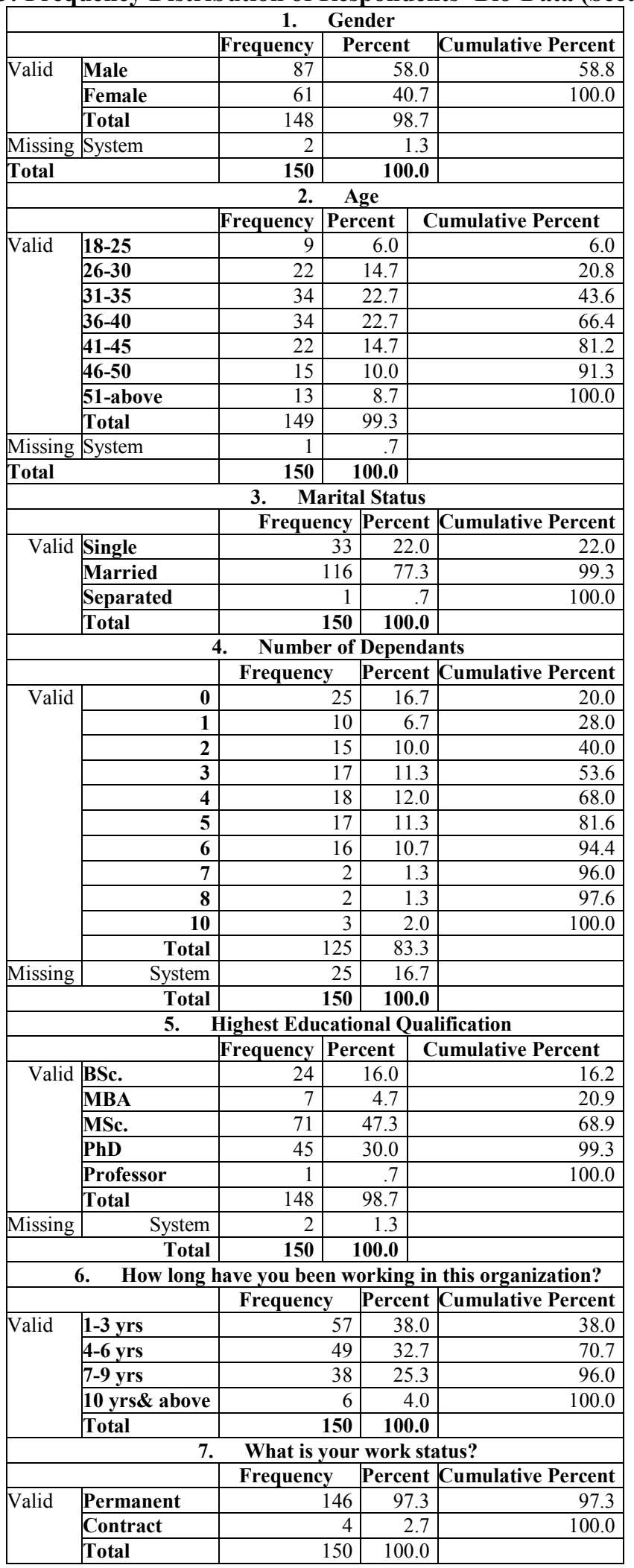

Source: Researcher's Field Survey (2014)

From table 3 above, $58 \%$ of the respondents were male and $40.7 \%$ of the respondents were female. The above table also showed that $6.0 \%$ of the respondents were within the age range of $18-25,14.7 \%$ of the respondents were within the age range of $26-30,22.7 \%$ of the respondents were within the age range of $31-35,22.7 \%$ of the respondents were within the age range of $36-40,14.7 \%$ of the respondents were within age range $41-45,8.7 \%$ of the respondents were within the age range of $46-50$ and $9.2 \%$ of the respondents were within the age range of 51- 
above.

The marital status of the respondents showed that $22.0 \%$ of the respondents were single, $77.3 \%$ of the respondents were married and $0.7 \%$ of the respondents were separated. Table 3 also shows that $16.7 \%$ of the respondent have zero dependants, $6.7 \%$ of the respondents have one dependant, $10.0 \%$ of the respondents have two dependants, $11.3 \%$ of the respondents have three dependants, $12.0 \%$ of the respondents have four dependants, $11.3 \%$ of the respondents have five dependants, $10.7 \%$ of the respondents have six dependants, $1.3 \%$ of the respondents have seven dependants, $1.3 \%$ of the respondents have eight dependants and $2.0 \%$ of the respondents have ten dependants.

The above table shows that $16.0 \%$ of the respondents have BSc, $4.7 \%$ of the respondents have MBA, $47.3 \%$ of the respondents have MSc, $30.0 \%$ of the respondents have $\mathrm{PhD}$ and $0.7 \%$ of the respondents are professors. Table 3 also shows that $38.0 \%$ of the respondents have been in the university for $1-3$ years, $32.7 \%$ of the respondents have been in the university for $4-6$ years, $25.3 \%$ of the respondents have been in the university for $7-9$ years and $4.0 \%$ of the respondents have been in the university for 10 years and above. The above table also shows that $97.3 \%$ of the respondents have permanent work status and $2.7 \%$ of the respondents have contract work status.

\subsection{Test of Hypotheses}

A standard multiple regression analysis was conducted to determine the contributions of independent variables (Predictors) on the dependent variable in Nigerian private universities. The results of this analysis revealed how much of the variance in the dependent variable can be explained by the independent variables (Predictors). The analysis also indicated the relative contribution of each independent variables (Predictors) on the dependent variable. The standard regression analysis also revealed the statistical significance of the results of both the independent variables (Predictors) and the dependent variable.

\subsubsection{Hypothesis One}

$\mathrm{H}_{1(0)}$ : The contributions of organizational ethics on employee rewards in Nigerian Private Universities are not significant.

\begin{tabular}{|c|c|c|c|c|}
\hline Model & $\mathbf{R}$ & R Square & Adjusted R Square & Std. Error of the Estimate \\
\hline 1 & $.287^{\mathrm{a}}$ & .082 & .037 & .80802 \\
\hline \multicolumn{5}{|c|}{$\begin{array}{l}\text { a. Predictors: (Constant), Wasted Time, Leisure, Degree of Gratification, Self-Reliance, Centrality of Work, } \\
\text { Hard Work, Morality } \\
\text { b. Dependent Variable: Reward }\end{array}$} \\
\hline
\end{tabular}

Source: Researcher's Field Survey (2014)

In table 4 above, after entry of the organizational ethics scale and employee rewards scale, the total variance explained by the model as a whole was $8.2 \%(.082 \times 100)$. This implied that organizational ethics scale explains $8.2 \%$ of the variance in employee rewards.

Table 5: ANOVA ${ }^{\mathrm{a}}$

\begin{tabular}{|c|c|c|c|c|c|}
\hline Model & Sum of Squares & df & Mean Square & $\mathbf{F}$ & Sig. \\
\hline \begin{tabular}{l|l} 
Regression \\
\end{tabular} & 8.332 & 7 & 1.190 & 1.823 & $.087^{b}$ \\
\hline Residual & 92.711 & 142 & .653 & & \\
\hline Total & 101.043 & 149 & & & \\
\hline
\end{tabular}

a. Dependent Variable: Reward

b. Predictors: (Constant), Wasted Time, Leisure, Degree of Gratification, Self-Reliance, Centrality of Work, Hard Work, Morality

Source: Researcher's Field Survey (2014)

Table 5 above gave assess to the statistical significance of organizational ethics on employee rewards. This analysis tested the null hypothesis that multiple $\mathrm{R}$ in the population equals 0 . The rule is that, a model reaches statistical significance when Sig. $=.000$; this really means that $p<.0005$. Therefore, from table 5 , Wasted Time, Leisure, Degree of Gratification, Self-Reliance, Centrality of Work, Hard Work, and Morality are not statistically significant to employee rewards where Sig. $=.087\{\mathrm{~F}(7,142)=1.823\}$.

In the model, table 6 below, only one of the organizational ethics had more statistical significance in predicting employee rewards, with the Degree of Gratification (DOG) scale recording a higher beta value (beta $=.206, p<.001$, Sig. .000) than the other organizational ethic variables. This implied that the variable, Degree of Gratification (DOG) is making a significant unique contribution to the prediction of the dependent variable, employee rewards than the other variables. 
Table 6: Coefficients ${ }^{\mathrm{a}}$

\begin{tabular}{|c|c|c|c|c|c|c|c|c|c|c|c|c|c|}
\hline \multirow{2}{*}{\multicolumn{2}{|c|}{ Model }} & \multicolumn{2}{|c|}{$\begin{array}{l}\text { Unstandardized } \\
\text { Coefficients }\end{array}$} & \multirow{2}{*}{$\begin{array}{c}\begin{array}{c}\text { Standardized } \\
\text { Coefficients }\end{array} \\
\text { Beta }\end{array}$} & \multirow[t]{2}{*}{$\mathbf{t}$} & \multirow[t]{2}{*}{ Sig. } & \multicolumn{2}{|c|}{$\begin{array}{c}95.0 \% \text { Confidence } \\
\text { Interval for B }\end{array}$} & \multicolumn{3}{|c|}{ Correlations } & \multicolumn{2}{|c|}{$\begin{array}{c}\text { Collinearity } \\
\text { Statistics }\end{array}$} \\
\hline & & B & $\begin{array}{c}\text { Std. } \\
\text { Error }\end{array}$ & & & & $\begin{array}{l}\text { Lower } \\
\text { Bound }\end{array}$ & $\begin{array}{l}\text { Upper } \\
\text { Bound }\end{array}$ & $\begin{array}{l}\text { Zero- } \\
\text { order }\end{array}$ & Partial & Part & Tolerance & VIF \\
\hline \multirow{8}{*}{1} & (Constant) & 3.381 & 1.033 & & 3.272 & .001 & 1.338 & 5.423 & & & & & \\
\hline & COW & .149 & .125 & .108 & 1.190 & .236 & -.099 & .397 & .065 & .099 & .096 & .781 & 1.281 \\
\hline & SR & .004 & .101 & .003 & .036 & .971 & -.196 & .203 & -.016 & .003 & .003 & .830 & 1.205 \\
\hline & HW & -.141 & .110 & -.118 & -1.280 & .203 & -.359 & .077 & -.039 & -.107 & -.103 & .761 & 1.314 \\
\hline & LEI & -.047 & .070 & -.055 & -.678 & .499 & -.185 & .091 & -.065 & -.057 & -.055 & .971 & 1.029 \\
\hline & MOR & -.384 & .214 & -.173 & -1.789 & .076 & -.808 & .040 & -.111 & -.148 & -.144 & .688 & 1.453 \\
\hline & DOG & .227 & .091 & .206 & 2.490 & .014 & .047 & .407 & .199 & .205 & .200 & .941 & 1.062 \\
\hline & WT & .215 & .183 & .114 & 1.171 & .244 & -.148 & .577 & .060 & .098 & .094 & .679 & 1.473 \\
\hline
\end{tabular}

Source: Researcher's Field Survey (2014)

Therefore, the results of the standard multiple regression analysis presented above, measuring the significant contribution of organizational ethic on employee rewards, the null hypothesis $\left(\mathrm{H}_{0}\right)$ was not rejected agreeing to it that the contributions of organizational ethics on employee rewards in Nigerian Private Universities are not significant.

\subsubsection{Hypothesis Two}

$\mathrm{H}_{2(0)}$ : The predictive capabilities of organizational ethics on employee work hours in Nigerian Private Universities are not significant.

\begin{tabular}{|l|c|r|r|r|}
\hline Model & R & \multicolumn{1}{|c|}{ R Square } & Adjusted R Square & \multicolumn{1}{c|}{ Std. Error of the Estimate } \\
\hline 1 & $.349^{\mathrm{a}}$ & $\mathbf{. 1 2 2}$ & .078 & .59241 \\
\hline
\end{tabular}

a. Predictors: (Constant), Wasted Time, Leisure, Degree of Gratification, Self-Reliance, Centrality of Work,

Hard Work, Morality

b. Dependent Variable: Hours Worked

Source: Researcher's Field Survey (2014)

In table 7 above, after entry of the organizational ethics scale and hours worked scale, the total variance explained by the model as a whole was $12.2 \%(.122 \times 100)$. This implied that organizational ethics scale explains $12.2 \%$ of the variance in employees' hours worked.

Table 8: ANOVA ${ }^{\mathrm{a}}$

\begin{tabular}{|l|l|r|r|r|r|r|}
\hline \multicolumn{2}{|l|}{ Model } & Sum of Squares & \multicolumn{1}{c|}{ df } & Mean Square & \multicolumn{1}{c|}{ F } & Sig. \\
\hline \multirow{3}{*}{1} & Regression & 6.908 & 7 & .987 & 2.812 & $.009^{b}$ \\
\cline { 2 - 7 } & Residual & 49.836 & 142 & .351 & & \\
\cline { 2 - 7 } & Total & 56.744 & 149 & & & \\
\hline
\end{tabular}

a. Dependent Variable: Hours Worked

b. Predictors: (Constant), Wasted Time, Leisure, Degree of Gratification, Self-Reliance, Centrality of Work,

Hard Work, Morality

Source: Researcher's Field Survey (2014)

Table 8 above also gave assess to the statistical significance of organizational ethics on employees' hours worked. This analysis tested the null hypothesis that multiple $\mathrm{R}$ in the population equals 0 . The rule is that, a model reaches statistical significance when Sig. $=.000$; this really means that $\mathrm{p}<.0005$. Therefore, from table 8 , Wasted Time, Leisure, Degree of Gratification, Self-Reliance, Centrality of Work, Hard Work, and Morality are not statistically significant to employees' hours worked where Sig. $=.009\{\mathrm{~F}(7,142)=2.812\}$.

Table 9: Coefficients ${ }^{\mathrm{a}}$

\begin{tabular}{|c|c|c|c|c|c|c|c|c|c|c|c|c|c|}
\hline \multirow{2}{*}{\multicolumn{2}{|c|}{ Model }} & \multicolumn{2}{|c|}{$\begin{array}{l}\text { Unstandardized } \\
\text { Coefficients }\end{array}$} & \multirow{2}{*}{$\begin{array}{c}\begin{array}{c}\text { Standardized } \\
\text { Coefficients }\end{array} \\
\text { Beta }\end{array}$} & \multirow[t]{2}{*}{$\mathbf{t}$} & \multirow[t]{2}{*}{ Sig. } & \multicolumn{2}{|c|}{$\begin{array}{c}95.0 \% \\
\text { Confidence } \\
\text { Interval for B }\end{array}$} & \multicolumn{3}{|c|}{ Correlations } & \multicolumn{2}{|c|}{$\begin{array}{l}\text { Collinearity } \\
\text { Statistics }\end{array}$} \\
\hline & & B & $\begin{array}{c}\text { Std. } \\
\text { Error }\end{array}$ & & & & $\begin{array}{l}\text { Lower } \\
\text { Bound }\end{array}$ & $\begin{array}{l}\text { Upper } \\
\text { Bound }\end{array}$ & $\begin{array}{l}\text { Zero- } \\
\text { order }\end{array}$ & Partial & Part & Tolerance & VIF \\
\hline \multirow{8}{*}{1} & (Constant) & 2.576 & .758 & & 3.400 & .001 & 1.078 & 4.073 & & & & & \\
\hline & COW & .054 & .092 & .052 & .586 & .559 & -.128 & .236 & .073 & .049 & .046 & .781 & 1.281 \\
\hline & SR & .086 & .074 & .101 & 1.166 & .245 & -.060 & .232 & .100 & .097 & .092 & .830 & 1.205 \\
\hline & HW & .003 & .081 & .004 & .041 & .968 & -.157 & .163 & .092 & .003 & .003 & .761 & 1.314 \\
\hline & LEI & .002 & .051 & .003 & .041 & .967 & -.099 & .103 & -.003 & .003 & .003 & .971 & 1.029 \\
\hline & MOR & -.334 & .157 & -.201 & -2.125 & .035 & -.645 & -.023 & -.064 & -.176 & -.167 & .688 & 1.453 \\
\hline & DOG & .204 & .067 & .248 & 3.056 & .003 & .072 & .336 & .276 & .248 & .240 & .941 & 1.062 \\
\hline & WT & .239 & .134 & .170 & 1.777 & .078 & -.027 & .504 & .154 & .147 & .140 & .679 & 1.473 \\
\hline
\end{tabular}

a. Dependent Variable: Hours Worked

Source: Researcher's Field Survey (2014)

In the model, table 9 below, only one of the organizational ethics had more statistical significance in 
predicting employees' hours worked, with the Degree of Gratification (DOG) scale recording a higher beta value (beta $=.248, p<.001$, Sig. .000) than the other organizational ethic variables. This implied that the variable, Degree of Gratification (DOG) is making a significant unique contribution to the prediction of the dependent variable, employees' hours worked than the other variables of organizational ethics.

Therefore, the results of the standard multiple regression analysis presented above, measuring the significant contribution of organizational ethic on employees' hours worked, the null hypothesis $\left(\mathrm{H}_{0}\right)$ was not rejected agreeing to it that the predictive capabilities of organizational ethics on employees' work hours in Nigerian Private Universities are not significant.

\section{Conclusions}

The intended objectives of this study was to determine the contributions of organizational ethics on employee rewards in Nigerian Private University and also on employee work hours. These objectives were tested in the hypotheses. It was clear from the study that organizational ethics does not play a significant role on employee level of productivity. It is therefore concluded that findings from the study will provide insights for employers and managers. Employee behaviors that are associated with strong work ethic can be further encouraged by good supervisions from employers and managers. By a proper reward of workers' expressions of positive work ethic attributes, managers and supervisors can still encourage increased productive work hours among employees and at the same time help accomplish organizational goals. Despite the results shown in this study regarding work ethic differences, organizational work ethics will continue to play a major role in the success of people at work in a technologically changing world. This results of this study were in consonance with Pogson, Cober and Doverspike (2003) that there is no significant relationship between organizational work ethics and rewards and hours worked.

\section{References}

Al-Ghazali, M. (1997). Akhlak seorang Muslim (Morals of a Muslim). Selangor: Thinker's Library Sdn.

Ali, A., and Falcone, T. (1995). Work ethic in the United States and Canada. Journal of Management Development, $14(6), 26-35$.

Al-Maududi, A. A. (1967). Islamic way of life. Islamic Research Academy, Karachi, Pakistan.

Brauchle, P. E. and Azam, M. S. (2004). Relationship between Selected Demographic Variables and Employee Work Ethics as Perceived by Supervisors. Journal of Industrial Teacher Education. 41(1).

Brauchle, P. E., and Azam, M. S. (2004). Factorial invariance of the occupational work ethic inventory (OWEI). Journal of Vocational Education Research, 29(2).

Campus Portal (2013). Top 100 Best University in Nigeria: 2013 University Ranking. Retrieved $11^{\text {th }}$ February, 2013, from http:/campusportal.com.ng/education/top-100-best-university-in-nigeria-2013-universityranking/1700/

Cherrington, D. J. (1980). The work ethic: Working values and values that work. New York: American Management Association.

Denka, A. (1994). Work ethic top job skill. CPA Journal, 64(9), 9-10.

Garner, G.D. (1984). Effects of Work Experiences in the United States on Work Attitudes of Mexican Immigrants. Athens, Georgia.

George, D., \& Mallery, P. (2003). SPSS for Windows step by step: A simple guide and reference. 11.0 update (4th ed.). Boston: Allyn \& Bacon.

Gwin (1985). Public Reason. Journal of Political and Moral Philosophy, 3(1)

Hill, R. B. (2005). Work Ethic and Employment Status: A Study of Jobseekers. Journal of Industrial Teacher Education, 42(3).

Hill, R. B., and Petty, G. C. (1995). A new look at selected employability skills: A factor analysis of the occupational work ethic. Journal of Vocational Education Research, 20(4), 59-73.

Kurland, N. (1995). Ethics, incentives, and conflicts of interest: A practical solution. Journal of Business Ethics; $14,465-475$

Maskawyh, A.I., (1961). Tadhîb al-akhlãq. DarMaktabah al-Hayah.

Mheta, Y. \& Joshi, S. (2010). Impact of Workplace Spirituality on Organization Culture through Improved Employee Productivity. Retrieved $1^{\text {st }}$ July, 2014, from http://www.academia.edu/636601/Impact_of_Workplace_Spirituality_on_Organization_Culture_throu gh_Improved_Employee_Productivity

Mote, J. Jordan, G. \& Hage, J. (2007). A Theories-Based Systemic Framework for Evaluating Diverse Portfolios of Scientific Work Part Two: Macro Indicators and Policy Interventions. Science and Public Policy 34(10), 731-741.

Nunnally, J. O. (1978). Psychometric theory. New York: McGraw-Hill.

Pogson, C. E., Cober, A. B., and Doverspike, D. (2003) Differences in self-reported work ethic across three career stages. Journal of Vocational Behavior, 62(1), 189-201. 
Pozen, R. C. (2008). Foundations to be laid before Bridging. Financial Times accessed on $28^{\text {th }}$ January, 2014 from http://hollis.harvard.edu/?itemid=|library/m/aleph $\mid 002010854$

Ranks Ng. (2013). Top 10 Private Universities in Nigeria, 2013. Retrieved 11 ${ }^{\text {th }}$ February, 2013, from http://www.ranksng.com/top-10-private-universities-nigeria/

Rogers, E. M. (1994). A history of communication study: A biographical approach. New York: Free Press.

Valentine, S. \& Barnett, T. (2003). Ethics Code Awareness, Perceived Ethical Values, and Organizational Commitment. Journal of Personal Selling and Sales Management, 23, 359-367.

Velasquez, M.G. (2006). Business Ethics: Concepts and Cases. Prentice-Hall, Inc. A Pearson Education Company, Upper Saddle River.

Yankelovich, D., and Immerwahr, J. (1984). Putting the work ethic to work. Society, 21(2), 58-76.

Young, J. L. (1986). What competencies do employees really need? A review of three studies. Journal of Career Development, 12(3), 240-249. 